\title{
IMPLEMENTASI PENERAPAN PROTOKOL KESEHATAN DI ERA NEW NORMAL PADA PEKERJA DI LOKA PENELITIAN KAMBING POTONG (LPKP) SEI PUTIH KECAMATAN GALANG
}

\section{SRI MELDA BR BANGUN1, ADE PUTRI HUSNIAWATI ${ }^{2}$, IKA NUR SAPUTRI ${ }^{3}$}

\author{
Institut Kesehatan Medistra Lubuk Pakam \\ Jl. Sudirman No.38 Lubuk Pakam Kec. Lubuk Pakam Kab. Deli Serdang, \\ Sumatera Utara \\ Email: meldabangun24@gmail.com \\ DOI : https://doi.org/10.35451/jkg.v4i1.870
}

\begin{abstract}
At the end of 2019 a new virus was discovered which is now an infectious disease outbreak around the world and WHO (World Health Organization) gives the name of the virus that is currently endemic as Covid-19 (Corona Virus Diseases 2019). This research is a qualitative research that aims to collect in-depth data from sources or informants by conducting direct interviews. The number of informants in this study were 10 people. The data collection is done by direct observation to field conducted in-depth interviews of workers and equipped with recording equipment sound made to 10 informants. The results of the research carried out are that there are workers who have not been able to carry out and implement health protocols in accordance with the recommendations of the government. Of the several health protocols that exist at the Slaughter Goat Research Workshop, there are health protocols that have been violated by workers, namely all workers do not wear masks when in the work environment, the absence of workers who apply physical or social distancing during work or during rest hours, water and hand washing soap are not provided and hand sanitizers are never used and are only for display in the office, and workers believe that it is impossible for fellow workers to transmit the Covid-19 virus to fellow
\end{abstract}


workers although there are already some workers in Loka Penelitian Kambing Potong who have contracted the virus, they are not worried and are not afraid of it. The advice that can be given is that workers must be aware of the importance of implementing health protocols and Loka Penelitian Kambing Potong should provide guidance and direction to workers in an effort to suppress the decline in Covid-19 cases.

\section{Keywords: Covid-19, Health Protocol}

\section{Pendahuluan}

Akhir tahun 2019 dunia dikejutkan dengan ditemukan virus baru Corona Viruses Diseases (covid 19). Virus ini bermula dari seorang yang terinfeksi di Wuhan, Provinsi Hubei, Cina pada 8 Desember 2019. Virus ini menyebar dengan cepat ke berbagai negara di dunia sehingga WHO menyatakan pandemi global (WHO, 2020).

Menurut WHO pada bulan Oktober 2020, kasus Covid-19 di dunia mencapai angka 36,7 juta, pada akhir bulan Januari 2021 kasus Covid-19 di dunia mengalami kenaikan yaitu mencapai angka 103 juta dan pada pertengahan bulan Februari 2021 kasus Covid-19 terus bertambah dan mengalami kenaikan yang sangat cepat yaitu mencapai angka 110 juta total kasus (WHO, 2021).

Berdasarkan data Covid-19 di Indonesia yang terkonfirmasi pada bulan Februari 2021 yaitu 1.334.634 kasus aktif, 1.142.703 orang sembuh, dan 36.166 ribu pasien meninggal (Satuan Tugas Penanganan Covid-19, 2021). Maka dari itu, pemerintah menetapkan virus Covid-19 sebagai status darurat bencana nasional, untuk mengatasi penyebaran virus, pemerintah membuat kebijakan patuh terhadap protokol kesehatan agar mencuci tangan pakai sabun dengan enam (6) langkah, tidak melakukan kontak langsung dengan orang lain, menjaga jarak baik itu physical distancing dan social distancing, menghindari pertemuan yang bersifat massal dan menggunakan masker saat keluar rumah, aktifitas bekerja, belajar dan beribadah pun juga dilaksanakan dirumah masing-masing (Ihsanuddin, 2020).

Protokol kesehatan adalah tata cara kegiatan yang dilakukan dalam rangka menjamin individu dan masyarakat agar tetap sehat dan terlindungi dari penyakit yang disebabkan oleh virus Covid-19.

Berdasarkan hasil observasi pada yang di lakukan tanggal 5 Februari 2021, ditemukan pekerja Lolitkambing belum sepenuhnya Penggunaan masker yang tidak tepat, lebih sering diletak di dagu dibandingkan di mulut, diletakan 
dimulut tetapi hidung tidak tertutup dengan alasan sesak jika digunakan lama, mencuci tangan yang belum menjadi kebiasaan, dan kebiasaan untuk berkumpul saat makan siang menjadi kendala dalam menjalankan protokol Kesehatan.

Berdasarkan hal tersebut diatas, peneliti tertarik untuk meneliti implementasi penerapan protokol Kesehatan di Era New Normal pada pekerja di Loka Penelitian Kambing Potong (LPKP) Sei Putih kecamatan Galang kabupaten Deli Serdang

\section{METOdE PENELITIAN}

Jenis dan rancangan penelitian ini adalah penelitian kualitatif yang bertujuan untuk menggali informasi dari informan dengan metode wawancara mendalam. Jumlah infoman adalah 10 informan dengan metode purposive sampling.

Pengumpulan data dengan menggunakan data primer dan data sekunder. Wawancara yang dilakukan dengan berpedoman pada kuesioner dan lembar observasi yang sudah dipersiapkan sebelumnya oleh peneliti sedangkan data sekunder diperoleh melalui studi pustaka dari buku, jurnal, internet, wawancara dengan pihak lain diluar narasumber, dan dari instansi terkait (Dinas Sosial Tenaga Kerja dan Transmigrasi Kabupaten Deli Serdang) serta referensi-referensi lain. Setelah data terkumpul, dilakukan validasi data dengan menggunakan uji kredibilitas. Kemudian dilakukan analisis data mulai dari tahap reduksi data, penyajian data, hingga penarikan kesimpulan/ verifikasi.

\section{HASIL}

Adapun protokol kesehatan yang sudah ada di Loka Penelitian Kambing Potong yaitu seperti penggunaan masker, dan terdapat juga tempat cuci tangan namun tidak ada air yang diisikan di dalam drum dan juga sabun cuci tangan yang sudah habis serta hand sanitizer yang hanya menjadi pajangan saja diakibatkan pekerja malas mencuci tangan setelah beraktivitas. Hal ini disampaikan salah satu informan dalam wawancara:

"Sebenernya udah ada fasilitas yang diberikan oleh Loka seperti sabun cuci tangan dan hand sanitizer, tetapi itu jarang dipakai pekerja ketika lagi bekerja dan pekerja disini paling mencuci tangan kalau mau makan aja selebihnya jarang dan hand sanitizer disini hanya seperti pajangan yang tidak perna digunakan"

Kemudian terdapat juga pekerja yang memakai masker hanya sekedar dapat memasuki area tempat kerja karena takut menjadi tidak hadir. Hal ini disampaikan oleh Suwardi selaku Satpam dalam wawancara mendalam :

"Iya disini kalau mau masuk kerja di cek dulu pakai masker apa gak, kalau misalnya gak pakai gak dibolehkan 
masuk. Tapi banyak juga yang bapak lihat, ada pekerja yang bawa masker tapi gak di pake langsung dari rumah tapi dipakenya waktu di depan gerbang agar mereka bisa masuk kerja tapi setelah sampai di parkiran langsung di buka kembali. Disini pun sebenernya ada alat cek suhu tapi udah rusak jadi gak bapak pake lagi untuk cek suhu pekerja sama tamu"

Dalam 4 minggu terakhir ada 1 orang lagi yang sudah terkonfirmasi virus Covid-19 sehingga terdapat 25 orang pekerja yang sudah terkonfirmasi virus Covid-19. Hal ini disampaikan oleh Silvia selaku Pegawai Perpustakaan pada saat melakukan wawancara mendalam :

"Disini sebenarnya dalam 4 minggu terakhir ada 1 orang yang kena Covid19 jadi jika di totalkan udah ada sekitar 25 orang yang terkonfirmasi virus Covid-19 ini dek."

Maka jika ada pekerja yang sudah terinfeksi virus Covid-19 langsung dibawa ke Cadika Lubuk Pakam untuk diisolasi selama 14 hari. Hal ini disampaikan oleh Handoko selaku Satpam pada saat melakukan wawancara mendalam :

"Pasien yang masuk di Cadika ini ya dirawat sama suster khusus Covid, terus mereka di rawat sampe sembuh dan di test rapid antigen tiap hari sampe hasilnya negatif kemudian mereka udah bisa pulang. Tapi selama pasien disini gak boleh keluarga menjenguk karena takut kalau keluarga akan terinfeksi virus Covid-19 juga"

Pasien yang sudah diisolasi selama 14 hari dan setelah itu mereka sembuh maka sudah diperbolehkan pulang. Dengan masih banyaknya pekerja yang belum menerapkan dengan baik protokol kesehatan di LPKP maka Gugus Tugas Covid-19 sudah datang untuk meninjau langsung berapa pekerja yang sudah terkonfirmasi virus Covid-19 dan juga melakukan sosialisasi mengenai percepatan penangan virus Covid-19 di Loka Penelitian Kambing Potong (LPKP). Seperti yang disampaikan oleh Erna Rieni Batu Bara selaku Pegawai Tata Usaha melalui wawancara mendalam :

"Pada bulan Agustus tahun lalu itu Gugus Tugas Covid datang untuk melihat apa pekerja disini jalankan protokol kesehatan apa gak, terus kami dikasih peringatan untuk membatasi seluruh kegiatan di luar rumah".

\section{PEMBAHASAN}

Berdasarkan hasil penelitian yang dilakukan didapatkan hasil penerapan protokol kesehatan di Loka Penelitian Kambing Potong Sei Putih Kecamatan Galang Kabupaten Deli Serdang yaitu terdapat pekerja tidak memakai masker, tidak menjaga jarak, tidak mencuci tangan setelah beraktivitas dan hampir semua pekerja meyakini bahwa sesama rekan kerja tidak mungkin 
menularkan virus ke rekan kerja yang lain.

Sejalan dengan penelitian Rachmawan (2020), menyatakan bahwa tingginya jumlah pelanggaran dan terjadi secara massif pada pekerja yang merupakan sebuah permasalahan sosial di Indonesia dalam konteks penanganan Covid-19, namun yang lebih mengkhawatirkan adalah "ketidakpedulian" atau "acuh tak acuhnya" pekerja terhadap protokol kesehatan. Dengan tidak menerapkannya protokol kesehatan sebenarnya mempertegas survei yang dilakukan oleh Hadi, dkk (2020) selaku Ikatan Alumni Fakultas Kesehatan Masyarakat, Universitas Airlangga menujukkan bahwasannya mereka mendapati $84,1 \%$ pekerja di antaranya tidak menggunakan masker serta $89,3 \%$ tidak menerapkan physical atau social distancing.

Dalam hal ini peneliti berasumsi bahwa tempat kerja dan juga pekerjanya belum dapat menerapkan protokol kesehatan sesuai dengan anjuran dari pemerintah. Dengan masih banyaknya pekerja yang melanggar aturan dari pemerintah membuat semakin meningkatnya penyebaran dan penularan virus Covid-19 di Indonesia.

\section{KESIMPULAN}

Kesimpulan dalam penelitian ini adalah : a. Seluruh pekerja tidak memakai masker ketika berada di lingkungan kerja

b. Tidak adanya pekerja yang menerapkan physical atau social distancing selama bekerja atau selama jam istirahat

c. Gugus Tugas Covid datang untuk meninjau langsung ke LPKP

d. Air dan sabun cuci tangan tidak ada disediakan serta hand sanitizer tidak pernah dipergunakan dan hanya sebagai pajangan yang berada di kantor

e. Pekerja meyakini bahwasannya sesama pekerja tidak mungkin menularkan virus Covid-19

f. Sudah ada 25 orang pekerja yang terinfeksi virus Covid-19 dan mereka diisolasi di Cadika Lubuk Pakam selama 14 hari

\section{DAFTAR PUSTAKA}

Agustino, Leo. 2020. "Analisis Kebijakan Penanganan Wabah Covid-19 Pengalaman Indonesia". Banten : Jurnal Borneo Administrator

Agustino, Muhammad Rizqi. 2020. "Adaptasi dan Kebiasaan Baru Huma Resource Department di Masa Pandemik Covid-19". Business Innovation \& Entrepreneurship Journal Vol. 2 No. 3

Direktorat Jenderal Pencegahan dan Pengendalian Penyakit Kementrian Kesehatan RI. 2020. 
"Pedoman Kesiapsiagaan

Menghadapi Corona Virus

Disease (Covid-19). Jakarta

Gugus Tugas Covid-19.2020. Peta

Sebaran Data Covid-19. Diakses

pada tanggal 27 Februari 2021

WebSite

https://covid19.kemkes.go.id

Ihsanuddin. (2020). Presiden Jokowi

Teken Keppres Tetapkan Wabah

Covid-19 Bencana Nasional.

Diambil kembali dari

Kompas.com:

https://nasional.kompas.com/re ad/2020/04/13/18101841/presi

den-jokowi-teken-keppres-

tetapkan-wabah-covid-19-

bencana-nasional

Irmayani, dkk. 2020. "Edukasi Tentang

Penerapan Protokol Kesehatan

Dalam Upaya Pencegahan Covid19 di Kabupaten Serdang Bedagai Provinsi Sumatera Utara". Deli Serdang : Jurnal Pengmas Kestra (JPK) Volume 1 Nomor 1

Kementrian Kesehatan Republik Indonesia. 2020. "Pedoman Pencegahan dan Pengendalian Corona Virus Disease (Covid19)". Kemenkes RI

Kementrian Kesehatan RI. 2020. Situasi Terkini Perkembangan Coronavirus Disease (Covid-19). Infeksi Emerging : Media Informasi Resmi Terkini Penyakit Infeksi Emerging. Diakses pada tanggal 5 Januari 2021 WebSite : https://covid19.kemkes.go.id

Keputusan Menteri Kesehatan RI No. HK. 02.01/MENKES/216/2020. Tentang Protokol Pencegahan Penularan Coronavirus Disease 19 (Covid-19) di Tempat Kerja

Keputusan Menteri Kesehatan RI No.

HK. 01./07/MENKES/328/2020. Tentang Panduan dan Pengendalian Covid-19 di Tempat Kerja Perkantoran dan Industri dalam Mendukung Keberlangsungan Usaha pada situasi Pandemi 2020

Peraturan Menteri Kesehatan RI No. 9 Tahun 2020 Tentang Pedoman Pembatasan Sosial Berskala Besar dalam Rangka Percepatan Penanganan Coronavirus Disease 19 (Covid-19)

Putri, Noviyanti Ririn. 2020. "Indonesia dalam Mengahadapi Pandemi Covid-19". Junal Ilmiah Universitas Batanghari Jambi 20(2) : 705-709

Susilo, dkk. 2020. Coronavirus Disease 2019 : Tinjauan Literatur Terkini. Jurnal Penyakit dalam Indonesia. Vol. 7 No. 1

Satuan Tugas Penanganan Covid-19 SUMUT. 2020. Prevalensi Data Covid-19 Sumatera Utara. Diakses pada tanggal 27 Februari 2021 WebSite

https://covid19.sumutprov.go.id L 
Jurnal Kesehatan Masyarakat \& Gizi, e-ISSN: 2655-0849

Vol.4 No.1 Edisi Mei-Oktober 2021

https://ejournal.medistra.ac.id/index.php/JKG

Received: 11 Oktober 2021 :: Accepted: 31 Oktober 2021 :: Published: 31 Oktober 2021

WHO. 2020. "Novel Corona Virus".

Diakses pada tanggal 5 Januari

2020 Website

https://www.eho.int/indonesia/n

ews/novel-coronavirus/qa-for-

public

Wiranti, Ayun dan Wulan. 2020.

"Determinan Kepatuhan

Masyarakat Kota Depok terhadap

Kebijakan Pembatasan Sosial

Berskala Besar dalam

Pencegahan Covid-19". Jurnal

Kebijakan Kesehatan Indonesia :

JKK1 Volume 09 No. 03 hal 117-

124 